\title{
SENI LUKIS KARIKATUR KARYA GM. SUDARTA
}

\author{
Jimin Budiyono \\ Program Pascasarjana \\ Institut Seni Indonesia Surakarta \\ JI. Ki Hadjar Dewantara No. 19 Kentingan, Jebres, Surakarta, 57126
}

Dharsono Sony Kartika

ISI Surakarta

\begin{abstract}
ABSTRAK
"Seni Lukis Karikatur Karya GM. Sudarta."ini memfokuskan permasalahan pada bagaimana latar belakang seni lukis karikatur GM. Sudarta, mengapa seni lukis GM. Sudarta bergaya karikatural dan bagaimana bentuk estetik seni lukis karikatur karya GM. Sudarta. Tujuan penelitian ini untuk memahami dan menjelaskan latar belakang seni lukis karikatur karya GM.Sudarta, memahami dan menjelaskan seni lukis GM. Sudarta yang bergaya karikatural, memahami dan menjelaskan serta menganalisa estetika seni lukis karikatur GM. Sudarta.Metode atau langkah-langkah penelitian ini menggunakan metode kualitatif. Lokasi penelitian di studio lukis GM.Sudarta Cisarua, Bogor Jawa Barat. Data yang diperoleh melalui observasi, wawancara dan dokumentasi (arsip). Analisis data menggunakan interaksi analisis dan interpretasi analisis dengan pendekatan kritik seni Dharsono Sony Kartika, untuk mengetahui makna estetiknya menggunakan teori estetika Monroe Beardsley.Hasil penelitian menunjukkan kepeduliannya rasa cinta bangsa seorang seniman (GM.Sudarta) kepada masyarakat, bangsa dan negara (Indonesia) yang baru dilanda krisis moral, penuh aib korupsi dan keadilan yang belum ditegakkan, dengan teriakan bahasa rupa "kita belum terlambat" masih ada waktu untuk perbaikan.
\end{abstract}

Kata kunci: Latar belakang, Karikatural, Estetika.

\begin{abstract}
"Seni Lukis Karikatur Karya GM. Sudarta." This issue focuses on how the background of GM Sudarta's caricature painting, why GM Sudarta painting is a caricature style and how the aesthetic forms of caricature paintings by GM Sudarta. The purpose of this research is to understand and explain the background of art caricature paintings by GM Sudarta, to understand and to explain the carikatural style GM Sudarta paintings, to understand and to explain and analyze the aesthetics of caricature paintings by GM Sudarta. The method or steps of this research use qualitative methods. Research location at GM Sudarta Cisarua painting studio, Bogor, West Java. Data is obtained through observation, interviews and documentation (archives). Data analysis uses the interaction of analysis and interpretation of analysis with Dharsono Sony Kartika's art criticism approach, to find out the anesthetics using Monroe Beardsley's aesthetic theory. The results of the research show the concern of the nation's love of an artist (GM Sudarta) to the people, nation and country (Indonesia) which has just been hit by a moral crisis, full of ignorance of corruption and justice that has not been upheld, with the cry of the visual language "we are not too late" there is still time for improvement.
\end{abstract}

Keywords: Background, Caricature, Aesthetics.

\section{A. Pengantar}

Sosok seniman tumbuh di tengah masyarakat karena dedikasi dan pengabdiannya melalui kerja kreatif atau melalui karya seni yang diwujudkan. Kehadiran seniman dan karyanya adalah proyeksi dan refleksi atas kehidupan yang dijalani bersama lingkungan beserta masyarakat sekitar.

Seni adalah karya cipta manusia yang diwujudkan di atas media dan dapat dinikmati keindahannya, yang tidak meninggalkan prinsip dan unsur atau kaidah-kaidah berkesenian, dengan tujuan untuk mencapai kepuasan lahir maupun batin. Seperti yang dijelaskan Agus Sachari bahwa seni (art) adalah hal-hal yang diciptakan dan diwujudkan oleh manusia, yang dapat memberi rasa kesenangan dan kepuasan dengan pencapaian rasa indah (Sachari, 2001 : 14).

Seni lukis karikatur adalah karya cipta manusia yang diekspresikan di atas media dua dimensional yang tidak meninggalkan prinsip dan unsur seni rupa, yang bergaya karikatur yakni mengutakan penonjolan yang berlebihan untuk mengkritisi seorang tokoh atau peristiwa penting. 


\section{GEEAR Jumal sai isubya}

Seni lukis karikatural diwujudkan seorang seniman untuk mengkritisi suatu fenomena atau kejanggalan yang terjadi dalam masyarakat bangasa dan Negara, untuk dimengerti isi dan makna estetiknya. Manfaat diwujudkan karya tersebut supaya masyarakat mengetahui contoh-contoh perilaku yang kurang baik supaya tidak ditiru dan dibudayakan.

Pendekatan yang digunakan adalah kritik sosial menggunakan metode analisis interpretatif data lapangan.yang menekankan pada sisi kualitasnya.

Seperti karya Seni lukis karikatur GM.Sudarta menarik untuk diteliti dan dikaji karena merupakan catatan pahit-getirnya fenomena kehidupan masyarakat Indonesia yang penuh aib korupsi, keadilan belum bisa ditegakkan, para pejabat berperilaku hewani, rakus dan hanya mementingkan dirinya sendiri. Karya seni lukis karikatur tersebut sangat menarik untuk diteliti dan dikaji karena di dalam karya tersebut mengandung pesan persoalan kehidupan manusia yang ada di muka bumi ini, terutama bangsa Indonesia yang serba runyam, konyol, penuh aib korupsi,sehingga pesan moral tersebut perlu disampaikan kepada masyarakat, dengan harapan supaya masyarakat mengetahui contoh-contoh perilaku yang kurang baik yangtidak pantas untuk ditiru dan dibudayakan. Karya-karya seni lukis karikatural tersbut mempunyai bentuk yang spesifik, dibanding karya-karya GM. Sudarta yang lain sehingga perlu diteliti untuk mendapatkan makna estetiknya.

\section{Seni Lukis}

Dharsono menjelaskan, seni lukis adalah suatu ungkapan pengalaman estetik seseorang yang dituangkan dalam bidang dua dimensi (dua matra), dengan menggunakan medium rupa, yaitu garis, warna tekstur, shape dan sebagainya (Dharsono, 2014 : 36).

Jadi karya seni lukis merupakan ungkapan jiwa yang berdasarkan pengalaman estetik maupun ideologis yang menggunakan unsur garis dan warna, yang didapat dari memperhatikan fenomena kehidupan manusia yang ada di muka bumi ini, yang dituangkan diatas media dua dimensi.

\section{Karikatur}

Karikatur menurut kamus lengkap bahasa Indonesia mengandung arti gambar sindiran, gambar olok-olok (yang biasa diterbikan dikoran atau majalah) (A.K. Muda, 2006 : 292). Namun Agus Sachari menjelaskan sebagai berkut.
Karikatur adalah seni gambar yang menggunakan penonjolan yang berlebihan untuk memperlihatkan ciri khas dari seorang tokoh, atau makna khas suatu peristiwa yang penting. Suatu ciri khas karikatur yang mutu adalah permainan goresan yang sedikit mungkin, yang jelas tanpa banyak hiasan dan sederhana. Kesederhanaan justru menciptakan komunikasi yang jelas, tegas dan efektif (Sachari, 2001:55-56).

Jadi seni gambar karikatur mengutamakan penonjolan suatu bentuk tertentu secara berlebihan dari seorang tokoh dengan goresan yang sedikit dan sederhana yang bisa menciptakan komunikasi yang jelas dan tegas.

Karikatur menurut Alex Sobur adalah, produk suatu keahlian seorang karikaturis, baik dari segi pengetahuan, intelektual, bacaan maupun bagaimana dia memilih topik yang tepat. Karena itu kita bisa mendeteksi tingkat intelektual seorang karikaturis dari sudut pandang ini. Juga cara dia mengkritik yang secara langsung membuat orang yang dikritik justru tersenyum (Sobur,2013:140).

Jadi karikatur adalah gambar yang mudah diingat dengan komentar satiris pendek yang bisa menghibur, dan di dalamnya mengandung kritikan, dan bertujuan mengejek untuk mendapatkan kehidupan yang lebih baik.

\section{Seni Lukis Karikatural}

Efix Mulyadi mengatakan, meski setiap kali disela dengan istirahat panjang untuk tetap bisa menjaga kondisi tubuh, toh ia mampu menyelesaikan 15 lukisan. Hampir semua lukisan tersebut berupa satir yang tajam, mengiris, dan membawa suasana yang muram. Karena rasa cinta bangsa yang sangat besar itulah ia melukiskannya, dengan hati teriris namun dibaliknya penuh harapan. ....Bedanya, humor selalu utama di dalam karikaturnya sehingga betapapun keras kritik tak akan membuat marah secara berlebihan, sedang di dalam lukisannya kadar humor sangat tipis (Mulyadi, 2011:6).

Berkaitan dengan itu menurut Efik Mulyadi, seni lukis karikatural adalah karya seni yang disajikan di atas media dua dimensi dengan kadar humor yang sedikit/tipis, dan mengandung kritikan yang pedas dan tajam. 
Keterangan Efix Mulyadi, dan Agus Sachari dapat disimpulkan bahwa, seni lukis karikatural adalah karya seni yang dituangkan di atas media dua dimensi dan menggunakan penonjolan yang berlebihan untuk memperlihatkan ciri khas seorang tokoh atau makna khas suatu peristiwa yang penting dengan sajian yang satir/lucu dengan kadar humornya yang sedikit atau tipis, namun mengandung kritik dengan tujuan mengejek seseorang untuk mendapatkan kehidupan yang baik. Perwujudan karya seni lukis tersebut menggunakan permainan goresan yang sedikit tanpa banyak hiasan dan sederhana, yang justru menciptakan komunikasi yang jelas dan tegas.

\section{Estetika}

Agus Sachari menjelaskan, penangkapan kesan dari luar yang menimbulkan nikmat-indah terjadi melalui dua panca indera kita, yakni melalui mata dan telinga. Yang melalui mata kita sebut kesan visual dan yang melalui telinga kesan akustis atau auditif.

Selanjutnya Agus Sachari menjelaskan, pengertian wujud, mengacu pada kenyataan yang nampak secara kongkrit (berarti dapat dipersepsi dengan mata atau telinga) maupun kenyataan yang tidak nampak secara kongkrit, yang abstrak, yang hanya bisa dibayangkan, seperti suatu yang diceritakan atau dibaca dalam buku (Sachari, 2001: 2 - 17).

Seperti karya seni lukis tersebut, dapat ditangkap dengan kesan dari luar dan menimbulkan nikmat dan indah melalui mata disebut kesan Visual. Namun mengacu pada kenyataan yang nampak secara kongkrit juga disebut wujud karya seni lukis.

Selebihnya Sachari menjelaskan, IImu Estetika adalah ilmu yang mempelajari segala sesuatu yang berkaitan dengan keindahan, mempelajari semua aspek dari apa yang kita sebut keindahan (Sachari, 2001:7).

Jadi mengkaji/meneliti seni lukis berarti mempelajari segala sesuatu yang indah pada perwujudan/visual karya tersebut.

A.A. M. Djelantik menjelaskan bahwa, semua benda atau peristiwa kesenian mengandung tiga aspek yang mendasar, yakni wujud atau rupa (appearance), bobot atau isi (content, substance) dan penampilan, penyajian (presentation) (Djelantik, 1999: 17).
Jadi setiap kegiatan atau aktivitas berkesenian yang menghasilkan karya atau benda seni memiliki tiga aspek yang mendasar yaitu, wujud, isi atau bobot dan penampilan sehingga karya seni tersebut mempunyai nilai estetik yang tinggi dan bukan hanya benda yang kosong belaka. Seperti karya seni lukis karikatur GM. Sudarta memiliki wujud, isi dan penampilan sehingga nikmat dipandang mata dan terkesan bila dihayati.

Peneliti menggunakan teknik analisis interaktif yang meliputi tiga variabel terhadap data-data hasil wawancara, studi pustaka dan dokumen atau arsip, yaitu penyajian data, reduksi data dan penarikan kesimpulan dengan tujuan untuk memudahkan proses jalannya penelitian yang dilakukan, sehingga peneliti membuat skema prosedur anlasis data yang disajikan dalam bentuk siklus.

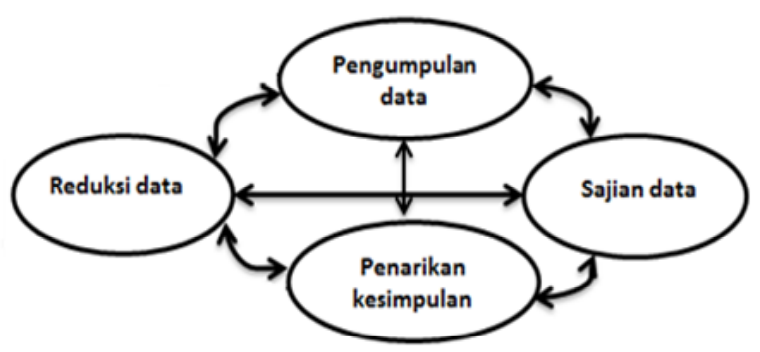

Gambar 1.

Skema analisis interaktif.

Proses analisis data dalam penelitian ini menekankan pada interaksi analisis dengan pendekatan kritik seni Dharsono Sony Kartika terhadap karya seni lukis GM.Sudarta yang bergaya karikatural, mejelaskan dan memahami serta menganalisa karya seni lukis karikatural GM.Sudarta, yang menekankan pada interpretasi analisis dengan pendekatan teori Estetika Monroe Beardsley yang mengarah pada bentuk estetik seni lukis GM.Sudarta yang bergaya karikatural, yang meliputi tiga unsur yakni:kesatuan (Unity), kerumitan (Complexity), kesungguhan (Intensity).

Skema analisis interpretasi dibawah ini sebagai berikut.

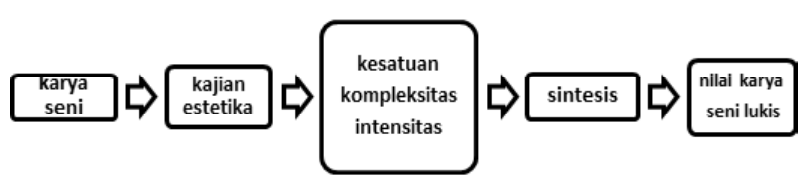

Gambar 2.

Skema interpretasi analisis. 


\section{GEEAR Jumal scii Bublya}

\section{B. Kelahiran Seni Lukis Karikatur GM. Sudarta}

Seperti halnya karya seni lukis karikatur GM. Sudarta, dapat dipahami dan dimengerti dengan pendekatan sejarah dan dianalisa menggunakan analisis interaktif yang melatarbelakangi kelahiran atas karya-karyanya.Seperti yang dikatakan oleh Jakob Sumardjo sebagai berikut:

Manusia kreatif adalah manusia yang memiliki kemampuan kreatif. Kemampuan kreatif antara lain kesigapan menghasilkan gagasan baru. Gagasan baru itu tentu baru muncul kalau seseorang telah mengenal secara jelas gagasan yang telah ada dan tersedia dalam lingkungan hidupnya. Tanpa mengenal dan menguasai budaya ditempat dia hidup tak mungkin muncul gagasan baru (Sumardjo, 2000:81-82).

Pendapat Sumardjo tersebut sangat mendukung lahirnya karya seni lukis karikatural karya GM. Sudarta yang dipengaruhi dan mengenal lebih jauh tentang karikatur di tempat bekerjanya pada surat kabar Kompas. Bab ini membahas latar belakang kelahiran seni lukis karikatur karya GM.Sudarta dengan pendekatan Sejarah,mengenai asal-usul pengalaman dan pengetauan yang dimiliki, yang dimulai dari menguraikan tentang gagasan awal munculnya seni lukis karikatur tersebut, konsep penciptaan karya, dan proses kreasinya karya tersebut diwujudkan. Uraian ini akan dibahas dan dianalisa menggunakan analisis interpretative berdasarkan datadata yang ditemukan dilapangan dan keterangan dari berbagai narasumber yang sekaligus sebagai teman dekatnya.

\section{Sebelum Tahun 2009}

Kontribusi yang sangat besar dan berharga terhadap munculnya bentuk-bentuk yang satiris pada karya seni lukis karikatur GM. Sudarta berasal dari pengalamannya selama bekerja menjadi seorang kartunis dan karikaturis pada sebuah perusahaan surat kabar Kompas di Jakarta, yang kurang lebih memakan waktu selama 38 tahun, dan berakhir pada tahun 2005. Namun sampai sekarang GM. Sudarta masih menjadi kontributor karikatur pada perusahaan surat kabar tersebut.

Di bawah ini contoh gambar karya karikatur GM. Sudarta yang telah dimuat dalam surat kabar Kompas pada tanggal 18 juli tahun 2000.

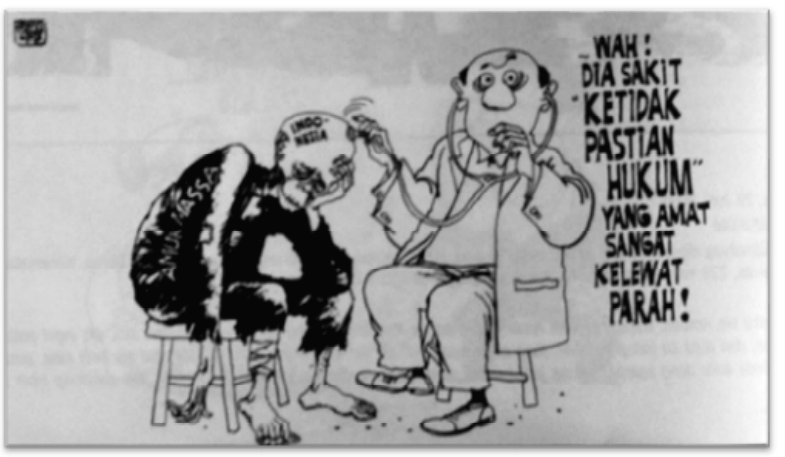

Gambar 3.

Karya Karikatur GM. Sudarta, Kompas 18 juli 2000. Bentrok antar warga dan amuk masa yang semakin merebak dimana-mana mencerminkan adanya ketidakpastian hukum dan tekanan ekonomi (Sudarta, 2007:176). (Repro foto, Budiyono : 2015)

Karikatur itu disajikan dalam bentukyang lucu, untuk mengkritisi fenomena yang terjadi di tengahtengah masyarakat.Karya dibuat hitam putih dengan garis yang tegas dan tulisan ditampilkan untuk memperjelas suasana gambar. Hal ini mempengaruhi dan mendasari munculnya gagasan karya seni lukis karikatur menjadi bentuk baru yang lebih estetis.

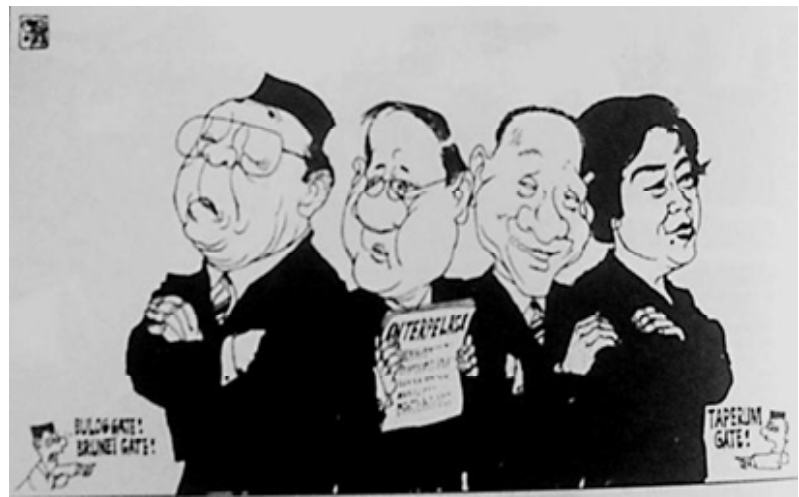

Gambar 4.

Karya Karikatur GM. Sudarta, Kompas 15 juli 2000. Rencana pertemuan empat tokoh, Presiden $\mathrm{KH}$.

Abdurrahman Wahid, Wakil Presiden Megawati, Ketua MPR Amin Rais, KetuaDPR Akbar Tanjung di Hotel Mulia ditunda dengan alasan yang tidak jelas (Sudarta, 2007 : 176). (Repro foto: Budiyono, 2015)

Karikatur GM. Sudarta menggunakan penonjolan yang berlebihan pada karakter tokoh dengan maksud mengkritisi suatu peristiwa untuk memperlihatkan ciri khas tokoh tersebut. Garis dibuat lebih tegas dan sempurna dengan tinta hitam, dan 
latar belakang dibiarkan kososng, diperjelas dengan tulisan untuk membuat lebih terang suasana dalam karya tersebut.Tokoh yang diambil selain Oom Pasikom, adalah para pejabat yang berperan dalam suatu peristiwa tersebut dengan cara mendisformasi menjadi bentuk baru dalam sajian yang lucu.

Pengalaman dan pengetahuan di bidang kartun dan karikatur selama bekerja di Kompas, yang melatarbelakangi munculnya karya seni lukis GM.Sudarta bergaya karikatural.

\section{Tahun 2009 Munculnya Seni Lukis Karikatural}

Setelah purna tugas dari pengabdiannya di surat kabar Kompas tahun 2005, GM. Sudarta kembali menekuni karya seni lukisnya, karena dengan melukis akan mendapatkan adanya keseimbangan jiwa. Sehingga mendorong untuk selalu berkarya.

Jadi gagasan yang mendorong memunculkan karya seni lukis karikatural adalah rasa prihatin melihat keadaan bangsanya yang dalam keadaan serba runyam karena banyak para pejabat yang terkena krisis moral.

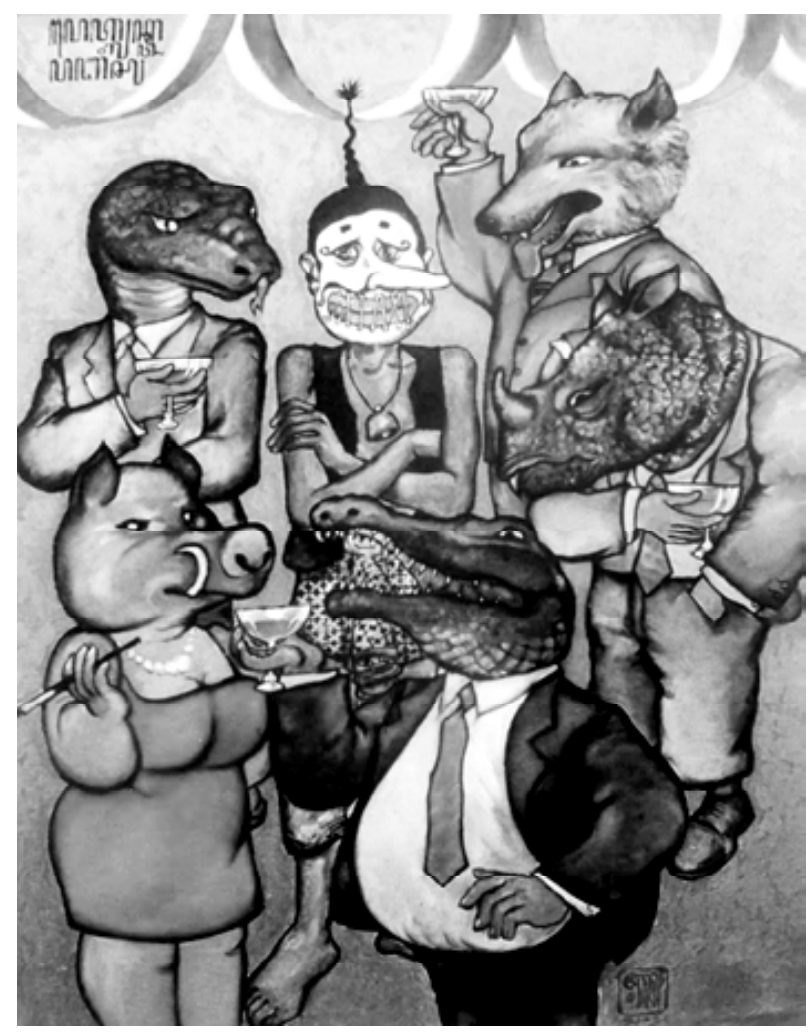

Gambar 5. GM. Sudarta (2009) Petruk Topo Bisu,90 $x 110 \mathrm{~cm}$. Cat minyak di atas kanvas.

( Foto: Budiyono, 2015)

\section{Sesudah Tahun 2009}

Berkat pengabdiannya di Perusahaan Surat Kabar Kompas, pengalaman dan pengetahuan GM. Sudarta semakin bertambah, dan menjadikan modal dalam menjalani kehidupan berkeseniannya selama purna tugas dari perusahaan surat kabar tersebut. Seorang seniman berkarya merupakan panggilan jiwa, yang rela berkorban demi kepentingan umat manusia, dengan harapan perbaikan perilaku moral manusia menjadi lebih baik demi ketentraman, kedamaian dan kesejahteraan dalam menjalani kehidupan di tengahtengah masyarakat.

Gejolak yang terjadi di tengah masyarakat, menbuat prihatin terhadap seorang seniman seperti GM. Sudarta, yang selalu memperhatikan fenomena kehidupan di masyarakat tersebut, dan kemudian diekspresikan di atas kanvas menjadi bentuk seni lukis yang bergaya karikatural. Sesudah tahun 2009 mulai bermunculan karya seni lukisnya yang bergaya karikatur, karena gejolak atau peristiwa yang terjadi di tengah masyarakat semakin runyam, keadilan dan kebenaran belum bisa ditegakkan, sifat rakus dan keangkaramurkaan para pemegang kekuasaan masih menjadi budaya di kalangan pejabat pemerintahan.

Terdapat empat pokok dalam konsep menciptakan karya seni lukis karikatural.

1. Kritikan

Kritikan, mengandung maksud mengkritisi perilaku persoalan manusia yang telah menyimpang dari adat, budaya, agama atau aturan hukum yang berlaku, supaya mereka sadar dan mengetahui bahwa perilakunya tidak pantas diterapkan dalam lingkungan masyarakat, sehingga menimbulkan rasa ketidaknyamanan, ketidaktentraman dan ketidakadilan.

2. Kecemasan

Kecemasan, mengandung arti terlalu cemas, gelisah, khawatir terhadap sesuatu yang bakal terjadi, sehingga ada kewaspadaan supaya tidak terjadi sesuatu yang tidak diinginkan yang berdampak kurang baik.

3. Keprihatinan

Keprihatinan, yang berarti sedih memikirkan sesuatu dan berusaha berjuang berbuat untuk menanggulangi seatu yang tidak diinginkan tidak terjadi, dalam hal ini seorang karikaturis berteriak lewat karya seni supaya didengar oleh mereka yaitu tokoh yang dikritsi. 


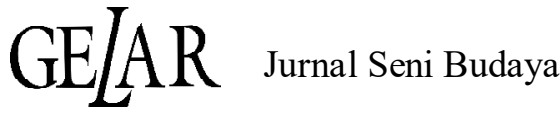

\section{Harapan}

Harapan yang dimaksud adalah mengharap sesuatu tentang apa yang dinginkan demi kebaikan bersama umat manusia yang menyangkut keadilan, kebenaran, ketentraman, kesejahteraan, kemakmuran, keamanan dan kenyamanan dalam menjalani kehidupan ditengah masyarakat.

Seni menurut Susanne K. Langer Sumardjo menjelaskan, seni mengenal tiga prinsip, yakni ekspresi, kreasi dan bentuk seni. Selebihnya mengatakan sebagai berikut:

Karya seni adalah bentuk ekspresi yang diciptakan bagi persepsi kita lewat indera dan pencitraan, dan yang diekspresikan adalah perasaan manusia.Pengertian perasaan dalam lingkup yang luas, yakni sesuatu yang dapat dirasakan, sensasi fisik, penderitaan dan kegembiraan, gairah dan ketenangan, tekanan pikiran, emosi yang kompleks yang berkaitan dengan kehidupan manusia (Sumardjo, 2000:66).

Penjelasan Sumardjo tersebut memberikan dukungan terhadap karya seni lukis karikatural GM. Sudarta. Perwujudan karya tersebut yang diekspresikan adalah perasaan manusia tentang penderitaan dan tekanan pikiran bangsa Indonesia yang mana keadilan dan kebenaran dalam melangsungkan kehidupan ditengah-tengah masyarakat belum bisa ditegakkan, yang kemudian divisualkan dalam bahasa rupa menjadi karya seni lukis karikatural dengan tujuan mengharapkan perbaikan sesuatu ketidakberesan yang melanda bangsa Indonesia tersebut.

\section{Seni Lukis GM. Sudarta Karikatural}

Karya seni lukis karikatural GM. Sudarta akan dibahas mengguakan pendekatan sejarah dan dianalisa menggunakan analisis interaktif. Karya seni lukis tersebut dapat terwujud karena rasa sosialnya seorang seniman yang sangat tinggi, sehingga peduli untuk mengekspresikan peristiwa apa yang terjadi di dalam masyarakat tersebut.

\section{Karya Seni Lukis Karikatur GM. Sudarta Sebuah Kritik}

Karya seni lukis karikatur merupakan karya seni yang punya tujuan untuk mengkritisi seseorang tokoh dan penyampaian pesan moral dengan misi perbaikan. Jadi GM.Sudarta membuat karya seni lukis karikatur dengan tujuan mengingatkan seseorang supaya sadar, bahwa perilaku seseorang tersebut kurang pantas untuk diterapkan dalam lingkungan masyarakat. Hal tersebut kalau dibiarkan terusmenerus berkembang di masyarakat, dan membuat tidak nyaman dalam menjalin hubungan sesama umat manusia. Maka dengan bahasa rupa GM.Sudarta angkat bicara lewat karya-karyanya yang divisualkan diatas kanvas, dalam hal ini GM.Sudarta (70 tahun) mengatakan sebagai berikut:

Kartun atau karikatur itu, kan punya misi perbaikan, dengan karya seni mengingatkan supaya mereka sadar untuk memperbaiki keadaan apa saja yang kurang baik, terutama peristiwa bangsa Indonesia ini yang baru mengalami pahit dan getir, dan kita masih banyak kesempatan untuk merubahnya (Sudarta, wawancara: 8 Juni 2015).

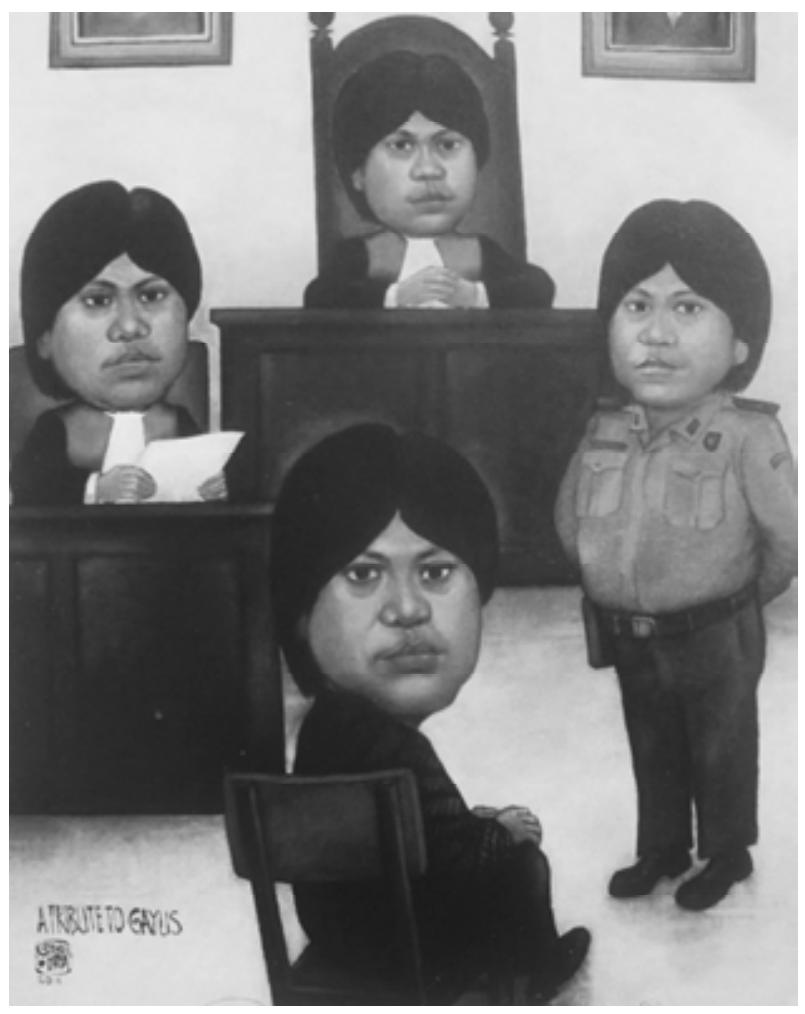

Gambar 6. GM. Sudarta (2011) A-Tribute To Gayus, $120 \times 100 \mathrm{~cm}$, cat minyak di atas kanvas. (Foto : Budiyono, 2015)

Contoh gambar tersebut di atas merupakan sebuah kritik terhadap aparat penegak hukum yakni jaksa, hakim, polisi dan terdakwa semuanya berwajah Gayus. Maksudnya terdakwa dan para aparat penegak hukum semuanya koruptor, mereka punya maksud yang sama. Sehingga keadilan dan kebenaran belum bisa ditegakkan. 


\section{Karya Seni LukisKarikatur GM. SudartaSatir dan Menghibur}

Sebuah karya seni perlu diabadikan karena merupakan catatan fenomena kehidupan yang ada dimuka bumi ini, sehingga suatu peristiwa masih dapat dikenali, walau kejadiannya sudah berpuluh-puluh tahun yang silam. Apalagi karya seni tersebut dengan sajian yang lucu, padahal di dalamnya mengandung kritikan yang pedas, sehingga para penikmat atau penghayat merasa nyaman dan terhibur, lagi pula orang yang dikritik tetap masih bisa tersenyum walaupun senyuman tersebut ternyata kecut.

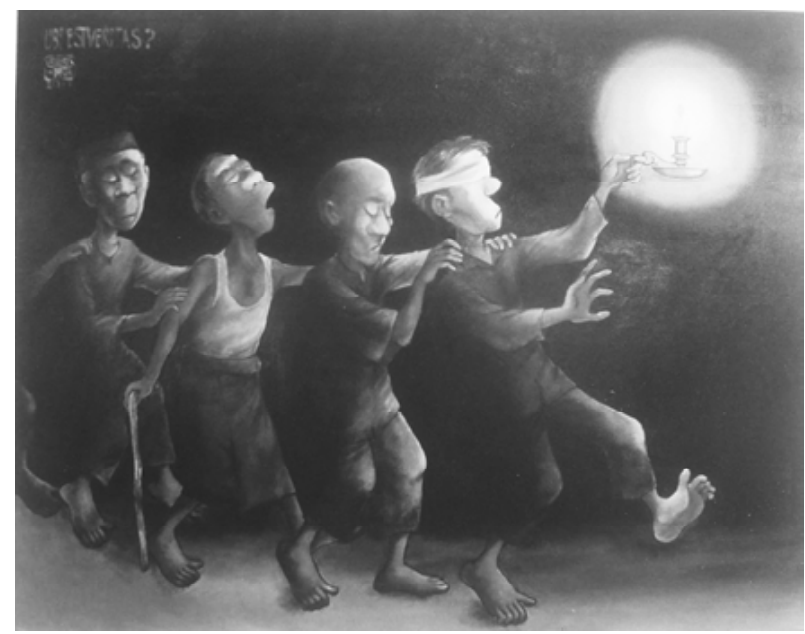

Gambar 7. GM. Sudarta (2011) Ubi Est Veritas, 90 x $120 \mathrm{~cm}$, mix media. (Foto: Budiyono, 2015)

Contoh gambar di atas disajikan dalam bentuk yang satir dan menghibur.Karena digambarkan seseorang terdepan sebagai penunjuk jalan orang buta di tengah kegelapan, yang membawa lampu penerangan tetapi matanya ditutup dengan kain.Visualisasi karya tersebut sangat lucu, unik dan menghibur, walaupun isi atau maknanya merupakan kritikan yang pedas, sehingga penikmat melihat karya seni tersebut langsung bisa tersenyum.

\section{Seni Lukis Karikatur GM. Sudarta Memberi Senyuman Kecut}

Seni lukis karikatur yang divisualkan GM.Sudarta cukup memberi suasana yang menggembirakan, setiap orang yang melihatnya akan tersenyum walaupun senyuman itu kecut, karena karya yang disajikan tersebut biasanya mengandung kritikan yang sangat pedas. Senyuman kecut yang diberikan oleh orang yang terkena kritik, bagi GM. Sudarta sangat berarti, karena komunikasi yang dilakukan lewat bahasa rupa dapat diterima. Maka dengan karya seni lukis karikatur bisa menghibur orang lain walaupun isi atau maknanya sangat menyakitkan. Bagi mereka yang tersindir akan sakit hati, karena aibnya dibaca atau diketahui orang lain, namun para penikmat bisa tertawa berbahak-bahak karena perilaku seseorang yang kurang baik ditampilkan menjadi bentuk karya seni yang lucu.

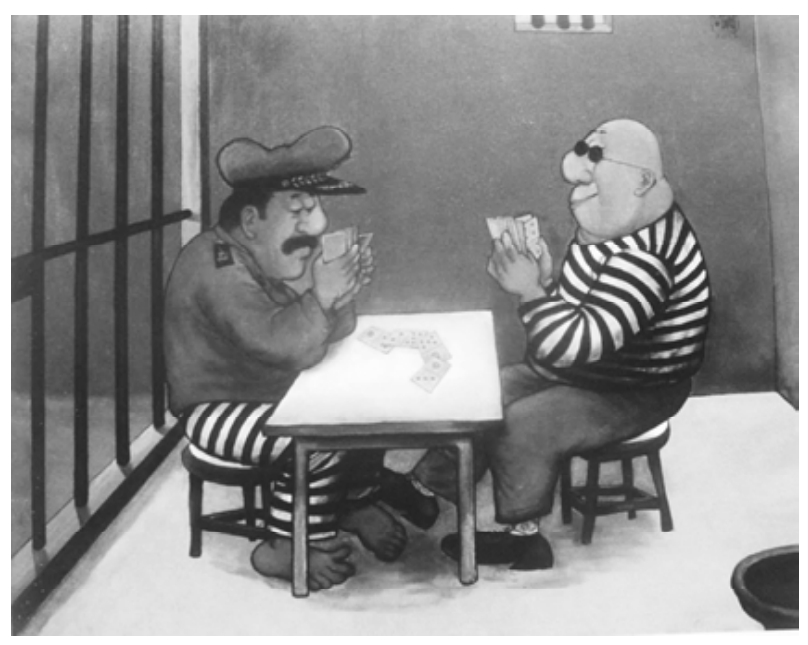

Gambar 8. GM. Sudarta (2011) HargaDiri 2, $80 \times 90 \mathrm{~cm}$, acrylic di atas kanvas.

(Foto: Budiyono, 2015)

Karya seni lukis Harga Diri 2 memberikan senyum kecut terhadap aparat penegak hukum, yang bersangkutan tidak sepantasnya mengenakan seragam yang saling bertukar dengan narapidana. Karya seni lukis tersebut merupakan kritik terhadap polisi penjara atau petugas keamanan yang menyalahgunakan wewenangnya, sehingga keadilan belum bisa ditegakkan.

\section{Estetika Seni Lukis karikatur Karya GM. Sudarta}

Karya tersebut akan dibahas dengan pendekatan kritik seni Dharsono Sony Kartika, dan dianalisis menggunakan teori Monroe Beardsley yang meliputi Kesatuan (Unity), kerumitan (Complexity) dan kesungguhan (Intensity).

\section{Seni Lukis PetrukTopo Bisu}

Karya seni lukis karikatur berjudul Petruk Topo Bisu terbuat dari bahan cat minyak di atas kanvas dengan ukuran $90 \mathrm{~cm} \times 110 \mathrm{~cm}$ dibuat pada tahun 2009 (lihat gambar : 5 halaman 39). Lukisan tersebut menunjukkan empat figur manusia yang mempunyai bentuk yang berbeda. Pertama.Seorang manusia 


\section{GEEAR Jumal sai isulyag}

berjas biru, berbaju putih dengan dasi merah dan berkepala buaya sedang memegang gelas berisi anggur merah yang memberi konotasi seorang buaya darat. Kedua, seorang perempuan mengenakan rok merah sambil memegang alat penghisap, dan berkepala babi, memberi konotasi wanita yang rakus. Ketiga, seorang pria berjas dan berdasi hijau sambil memegang gelas bersi anggur merah, berkepala badak, memberi konotasi seorang yang jahat. Keempat, seorang pria berjas coklat sambil memegang gelas bersi anggur merah dan berkepala srigala memberi konotasi orang yang jahat dan kejam. Kelima, seorang pria berwajah petruk warna putih memberi konotasi rakyat jelata yang jujur. Keenam, seorang pria berjas abu-abu, berdasi dan memegang segelas anggur merah yang berkepala ular memberi konotasi manusia penjilat. Background dibuat dengan warna kuning kecoklatan yang memberi kesan panas.

Karya seni lukis karikatur tersebut diciptakan untuk mengkritisi keadaan atau fenomena bangsa Indonesia yang baru carut marut, sebagian para pejabatnya penuh aib korupsi, rakus, suka foya-foya dan hanya mementingkan dirinya sendiri ataupun kelompok. Keadilan dan kebenaran belum bisa ditegakkan. Peristiwa tesebut dilukiskan dengan cara mentransformasi bentuk binatang dan manusia dengan bahasa metafora, yang divisualkan dalam bentuk manusia berkepala binatang yang sedang berpesta miras.

Unity (kesatuan) unsur-unsur visual seperti garis, bidang, warna, tekstur, gradasi membentuk kesatuan yang harmonis di atas media dua dimensi atau kanvas dengan ukuran empat persegi panjang. Kualitas unsur garis tepi atau kontur dibuat tegas, gradasi warna sedikit flat atau datar.Gradasi warna yang membentuk tekstur semu menghasilkan volume sehingga menimbulkan nuansa kontras.Pembentukan latarbelakang dengan warna kuning kecoklatan yang dibuat datar dan tanpa mengenal perspektif,warna background terkesan panas.Komposisi atau prinsip tata susun antara garis, warna, tekstur, gradasi menyatu dalam satu bidang dua dimensional sehingga sesuai dengan asas tata susun unsur seni rupa, pembuatan komposisi dari bentuk-bentuk manusia berkepala binatang disusun secara asimetri, sehingga menimbulkan kesan dinamis, dalam hal tersebut menghasilkan karya seni yang indah dipandang mata. Kesan yang dicapai pada penyusunan anatara garis, warna, tekstur, dan gradasi membentuk karya seni yang terkesan dekoratif, dan menunjukkan karakteristik tersendiri.
Complexity (kerumitan) yang dicapai terletak pada penyusunan antara garis dan warna yang dibuat penuh kesabaran dan berhati-hati, tekstur dan gradasi walaupun kurang memperhatikan gelap terang dan sedikit flat dalam pembuatan bentuk-bentuk manusia yang bekepala binatang dibuat cukup rumit sehingga menghasilkan karya seni yang estetik.

Intensity (kesungguhan) yang nampak kepermukaan karya tersebut terlihat pada penyusunan garis yang kuat, warna yang kontras, dan bentuk yang menyatu dalam satu bidang. Karya seni lukis tersebut dibuat dengan sungguh-sungguh dan memperhatikan prinsip seni rupa. Latar belakang dibuat datar karena GM. Sudarta masih berpegang teguh pada prinsip pembuatan karikatur yakni sedikit goresan dan tidak banyak hiasan yang menghadirkan suasana jelas dan tegas. Keunikan karya seni lukis karikatur tersebut adalah transformasi antara binatang dan manusia menjadi bentuk baru yang lucu sehingga menghasilkan karya seni yang nikmat dipandang mata dan terasa unik bila dihayati mengenai isi yang terkandung di dalamnya.

Makna dari lukisan tersebut adalah rakyat jelata yang menunjukkan kekesalannya dan tidak mau berkata sepatahpun yang dilambangkan dengan perwujudan Petruk yang mulutnya dijahit dan berdiri ditengah-tengah para pejabat yang sedang pesta miras, hal ini merupakan peringatan yang sangat keras terhadap para pejabat dan konglomerat di Indonesia yang sudah rakus tidak punya perasaan dan berperilaku hewani/seperti binatang, maunya menang sendiri, yang sudah tidak peduli pada rakyat kecil.

\section{E. Kesimpulan}

Hasil penelitian yang telah dipaparkan pada bab-bab sebelumnya, merupakan jawaban atas permasalahan yang dirumuskan, yang sesuai dengan metode dan analisis yang digunakan, serta dapat disimpulkan sebagai berikut:

a. Perwujudan karya seni lukis karikatural GM.Sudarta dipengaruhi pengalaman dan pengetahuannya waktu bekerja di Surat Kabar Kompas sebagai seorang kartunis dan karikaturis, sehingga membentuk karya seni yang baru dan punya karakteristik tersendiri.

b. Karya seni lukis karikatural GM.Sudarta, diciptakan untuk mengkritisi fenomena kehidupan manusia yang ada di muka bumi ini, karena para pelaku yang dikritik telah menyimpang dari disiplin aturan hukum yang berlaku, dan meresahkan masyarakat. 
c. Karya seni lukis karikatural GM.Sudarta diciptakan karena pengabdiannya yang tinggi sebagai seorang seniman terhadap bangsa dan tanah air, sehingga mengingatkan para pelaku yang menyimpang dari aturan/hukum yang ada dengan bahasa rupa yang satir, supaya sadar untuk memperbaiki perilakunya yang kurang baik.

\section{KEPUSTAKAAN}

Djelantik, A.A.M. Estetika Sebuah Pengantar, Bandung: MSPI,1999.

Dwi Marianto, M. Dinamika Bentuk dan Ruang.Jakarta : Fajar Sidik, 2006.

Mulyadi, Efix. Dan Sindhunata, Asam Garam Bentara, Jakarta : Bentara Budaya, 2014.
Mualyadi, Efix. Pameran Cinta GM. Sudarta, Jakarta: Rosemata, 2011.

Sachari, Agus. Estetika. Bandung: ITB, 2001.

Sony Karika, Dharsono. Kritik Seni. Bandung: Rekayasa Sains, 2007.

Sony Kartika, Dharsono. Seni Rupa Modern, Bandung: Rekayasa Sains, 2004.

Sudarta, GM. Indonesia 1967-1980. Jakarta:PT. Gramedia,1980.

Sumardjo, Jakob. Filsafat Seni, Bandung: ITB,2000.

Sobur, Alex. Semiotika Komunikasi, Bandung: Rosa Karya, 2003. 